\title{
The impact of climate change on the household food security of upland rice farmers in Sidomulyo, Lampung Province, Indonesia
}

\author{
KTUT MURNIATI ${ }^{1, \bullet}$, ABDUL MUTOLIB ${ }^{2, v \vee}$ \\ ${ }^{1}$ Department of Agribusiness, Faculty of Agriculture, Universitas Lampung. J1. Sumantri Brojonegoro No 1, Rajabasa, Bandar Lampung 35141, \\ Lampung, Indonesia. Tel.: +62-721-704946, Fax.: +62-721-770347, ^email: ktutmurniati@gmail.com \\ ${ }^{2}$ Program of Agricultural Extension, Faculty of Agriculture, Universitas Lampung. Jl. Sumantri Brojonegoro No 1, Rajabasa, Bandar Lampung 35141, \\ Lampung, Indonesia. Tel.: +62-721-704946, Fax.: +62-721-770347, ^^email: amutolib24@yahoo.com
}

Manuscript received: 26 April 2020. Revision accepted: 8 July 2020.

\begin{abstract}
Murniati K, Mutolib A. 2020. The impact of climate change on the household food security of upland rice farmers in Sidomulyo, Lampung Province, Indonesia. Biodiversitas 21: 3487-3493. Climate change in the agricultural sector, particularly food crops, significantly decreases the production, causing the anomaly influences of El-Niño (drought) and La-Nina (flood). Climate change will have an impact on food availability and accessibility, thereby disrupting the food security and vulnerability of farmer households. This study aimed to: analyze the livelihood vulnerabilities, determine the food security level, and assess the livelihood vulnerability on the food security of upland rice farmer households against climate change. This study was conducted in Sidomulyo Sub-district, South Lampung District. The samples were randomly selected among farmers, resulting in 66 selected farmers. The analysis included: the livelihood vulnerability index - intergovernmental panel of climate change (LVI-IPCC), food security index based on the Indonesian Institute of Sciences, and the Ordinal Model Logit (Ologit). The results showed that the upland rice farmer's household had a livelihood vulnerability of 0.071 , belonged to the medium category. Most farmer households $(77.27 \%)$ were categorized as food secure. The "secure" category in the food security index is obtained if the upland rice farmers fulfill three criteria includes food availability, food stability, and food sustainability. The strategy of climate change adaptation, rice price, and phonska fertilizer price affects the food security of farmers' households. Climate change adaptation strategies are indispensable for sustainable food security.
\end{abstract}

Keywords: Climate change, food security, upland rice, vulnerability

Abbreviations: Ologit: Ordinal Model Logit, LVI: Livelihood vulnerability index, LVI-IPCC: The livelihood vulnerability indexintergovernmental panel of climate change, PTT: integrated crop management

\section{INTRODUCTION}

One of the world's important issues is climate change and food security problems (Misra 2014; Islam and Wong, 2017, Zwane, 2019). Global climate change affects all human life aspects, including the agricultural sector (Ali et al. 2017; Thornton et al. 2018; Raza et al. 2019). The seasonal food crop is the most vulnerable affected by climate change, especially El-Niño and La-Nina (Mutolib et al. 2017; Sintayehu 2018; Eitzinger 2018). Climate (environment) is part of the three legs of the triangle (host, pathogen, and environment). Climate change, which includes increases in temperature, moisture, and $\mathrm{CO} 2$, can impact all three legs of the plant disease triangle in various ways (Francl 2001). Weather elements have a role important in creating environmental conditions that are suitable for the development of the disease (Bande et al. 2015). Climate change causes the increasing the water consumption, accelerating the fruit/seed maturation, decreasing the harvest quality, and decreasing the food crop productivity (Korres et al. 2016; Fahad et al. 2017; Ferrante and Mariani, 2018).

El-Niño and La-Nina can cause the harvest failure (Utami, Handayani, and Kuswantoro 2019) and significantly decline the crop production due to the prolonged drought and continuous rain that causes a flood (Gateau-Rey et al. 2018; Rodysill et al. 2019; Rahmat et al. 2019; Rahmat et al. 2020). Rice is a commodity that is affected by climate change, especially El Nino. The area of rice field in Indonesia in 2018 is 14.72 million hectares (Ministry of Agriculture of Indonesia 2018). The conventional system's lowland rice in Indonesia requires at least $655 \mathrm{~mm}$ in one planting period (100 days) (Fuadi et al. 2016). The El Nino phenomenon has directly reduced rice production in Indonesia by 2.9\% (Wahyu et al. 2011; Santoso 2016). Murniati et al. (2017) concluded that $60 \%$ of organic rice farmers in the Pematangsawa sub-District, Lampung Province, experienced harvest failure, while $40 \%$ experienced a declined production in 2012. As for nonorganic rice farmers, $52.8 \%$ experiences harvest failure, while $47.2 \%$ experienced a decline production due to the drought problem in 2012.

Farmers are very vulnerable to climate change as the farmer's livelihood depends on the nature condition (Srivastava and Rai 2012; Harvey 2014; Rahmat et al. 2018; Mashizha 2019). The impact of climate change not only affects the food production, but also influences the farmers' income, food accessibility, food supply, and food security (Asmare and, Meheret 2018; Firdaus et al. 2019; Anríquez and Toledo 2019). Murniati et al. (2019) 
concluded that the farmers' households were mostly in less food secure categories based on food availability, food accessibility, food stability, and food quality due to the climate change impact. Widada et al. (2014), concluded that based on the calculations of LVI and LVI-IPCC, farmer households in the urban region had greater livelihood vulnerability than the farmer households in rural areas due to the climate change.

The rice farming business dominates the rice production in Indonesia in the common paddy field, however in the recent years, the paddy field area declines due to the land function alteration for activities outside of the paddy field farming business (Komariah et al. 2015; Prajanti and Susilowati 2016; Listiana et al. 2019). To fulfill the rice, rice farming in dryland is potentially developed. According to the Indonesian Ministry of Agricultural Affairs (2016), more than 110.00 ha on every year, the rice field land alters its function, therefore optimizing the dry land as alternative upland rice can be used to overcome the land altered function.

Lampung Province is a rice production center in Indonesia, specifically Sidomulyo Sub-district, South Lampung District that becomes the center of upland rice production in the field. The upland rice productivity in Sidomulyo Sub-district is still low, namely 1.95 ton/ha (Murniati et al. 2019). Toha (2007) mentioned that the upland rice (padi gogo) productivity in Lampung with the integrated crop management (PPT) pattern and superior variety rice type used could increase the rice productivity up to 5.8 tons/ha. The low productivity of upland rice in Sidomulyo is due to the rice seed variety used is not grown for in the dry land (field), but only for paddy fields (Ciherang varieties), besides the production facilities (fertilizers and seeds) are in the unsuitable recommendations and the low farmer knowledge about the upland rice cultivation. In addition, climate change also contributes to the low productivity of upland rice. This study analyzed the upland rice farmer household livelihood vulnerability against the climate change, food security index, and the relationship of climate change on the upland rice farmer household food security in Sidomulyo SubDistrict, South Lampung District, Lampung Province, Indonesia.

\section{MATERIALS AND METHODS}

\section{Study area and time research}

This study was conducted in Bandar Dalam and Campang Tiga Villages, Sidomulyo Sub-district, South Lampung District, Lampung Province, Indonesia. Locations were chosen based on the purposive method with consideration as the central productions of the upland rice in Lampung Province. The study was conducted between April and June 2018 and between April and June 2019 with the consideration that upland rice is planted only once a year between December and March. Therefore, research is carried out post-harvest in order to be able to identify access and food security of upland rice farmers.

\section{Materials and equipment}

Materials and equipment used in this study included: Questionnaires containing some questions related to the vulnerability of climate change, food security conditions utilized to collect the primary data from the farmers. Data and information collected include data on respondent data, frequency of food, food source, type of food, accessibility of food sources, continuity of food supply, identity of upland rice farming, as well as other data that support research.

\section{Methods and data types}

The method used in this study was the survey method. Data collection was conducted through the profound observation and investigation to retrieve information on a set of a particular problem in a specific region. Data types retrieved were the primary data, i.e., the climate condition, upland rice business, food consumption and release, farmer's characteristics, and farmer's income. The secondary data were taken from related institutions and online sources. Data were collected by the direct interview with the respondents through the structured questionnaires and observation in the study locations to determine the specific condition of the farmer's business, society's social condition, and farmer respondents' household condition. The total respondents were 66 upland rice farmers, who were taken randomly.

The general description of respondents is: the average age of the respondent is 41.12 years, the average level of education is 8 years, and the average number of family members is 4 peoples. Farmers on upland rice very rarely have side jobs, and only $3.03 \%$ of all farmers have side jobs as laborers. The average area of upland rice owned by farmers is 0.62 hectares with productivity per hectare of 1.95 tons. The varieties used by most farmers are IR-64 $(66.67 \%)$ and Ciherang $(27.27 \%)$, and $6.06 \%$ of farmers grow other varieties.

\section{Data analysis}

The vulnerability rate of farmer's household livelihood against the climate change

The vulnerability rate of farmer's household livelihood against climate change was analyzed using the Livelihood vulnerability index (Hanh et al. 2009 and modified by Murniati et al. 2017). The main indicators of LVI were exposure, sensitivity, and adaptive capacity, and then the sub-indicators are presented in Table 1.

The steps to calculate the livelihood vulnerability index (LVI) were:

\section{Make the standard index size}

$$
\text { Index }_{\mathrm{s}}=\frac{s_{-} s_{\min }}{S_{\max }-s_{\min }}
$$

Where:

$\mathrm{S}$ is the real value of the main subindicators, dan $S_{\min }$ and $S_{\max }$, as the minimum and maximum value of the main of sub-indicator. 


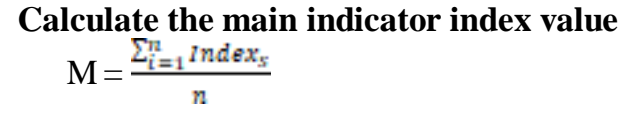

Whereas: $\mathrm{M}=$ One of the seven main indicators average: Farming (F), Food (Fd), Water (W), Consumption (C), Education (Ed), Income (I), as well as Natural disaster and Climate variation (BAVI), Index is the sub-indicator index- $i$, and $n$ is the total of sub-indicators.

\section{Calculate the livelihood vulnerability index (LVI)}

$$
\mathrm{LVI}_{\text {upland rice farmer }}=\frac{\sum_{i=1}^{\mathrm{J}} W_{M i} M}{\sum_{i=1}^{\mathrm{J}} W_{M i}}
$$

Where: LVI upland rice farmer is the average of seven main indicators measured, WMi is the total of sub-indicator from each main indicator. LVI ranges from $0.0-0.5$. LVI obtained the value of approaching 0.5 means that the household is susceptible/vulnerable while approaching 0.0 means almost no vulnerability/vulnerability observed.

1) Calculate the contribution of LVI-IPCC

$$
\mathrm{LVI}-\mathrm{IPCC}=(\mathrm{e}-\mathrm{a})^{*} \mathrm{~s}
$$

Where: $\mathrm{e}$ is the exposure index, a is the adaptation capacity index, and $\mathrm{s}$ is the sensitivity index. LVI-LPCC value ranges -1 (low vulnerability) to +1 (high vulnerability).

\section{Food security index of upland rice farmer household}

The food security index of upland rice farmer household was calculated using the indicators based on Aswatini et al (2004), namely (i) adequate food supply, (ii) food supply stability, (iii) food accessibility, and (iv) food quality and security.

\section{Adequate food supply}

The adequate food supply in the household was measured from the adequate main food consumed in a certain amount and period categorized as: (i) When the household food supply is $>/=240$ days (based on the field condition), the household food supply is adequate. (ii) When the household food supply is between 1 and 239 days, the household food supply is less adequate. (iii) When the household has no food supply, the household food supply is inadequate.

\section{Food supply stability}

The household food stability was measured based on the adequate food supply and consumption frequency of household members in a day categorized on Table 2.

\section{Food accessibility}

The food accessibility in the household was measured from the ease access of the household to gain food categorized as presented in Table 3.

The combination of food accessibility and food supply stability obtained the indicator of continuous food security as presented in Table 4.

\section{Food quality and security}

The size of food quality can be seen from the recommended dietary allowances containing adequate energy and protein related to food consumption (side dishes), whether containing animal or plant protein. The combination of continuous food supply and quality is the indicator of household food security, as presented in Table 5.

\section{The correlation of livelihood vulnerability and security against climate change}

The analysis to identify the correlation of livelihood vulnerability and security against the climate change approach by including some aspects to assess the livelihood vulnerability into the factors influencing food security, namely: Climate change adaptation strategy, the head of the family educational background, and income. Thereby, these factors were formulated as:

$\operatorname{Pr}\left(y_{j}=i\right)=\alpha_{o}+\beta_{1} \ln X_{1}+\beta_{2} \ln X_{2}+\beta_{3} \ln X_{3}+\beta_{4} \ln X_{4}+\beta_{5}$ $\ln X_{5}+\beta_{6} \ln X_{6}+\beta_{7} \ln X_{7}+\beta_{8} \ln X_{8}+\beta_{9} \ln X_{9}+\beta_{10} \ln X_{10}+$ $\beta_{11} \ln X_{11}+\mu$

Where:

$\operatorname{Pr}\left(y_{j}=i\right)=$ The probability of upland rice farmer household food security degree, whereas $i=1,2,3$,

3 = food Secure

$2=$ Less food Secure

$1=$ food Insecure

$\alpha=$ intercept

$\beta=$ regression coefficient (approached parameter) ( $\mathrm{i}=1$ to 11 )

$\mathrm{X}_{1}=$ climate change adaptation strategy in the upland rice farming business (total).

$\mathrm{X}_{2}=$ the head of the family educational background (years old)

$\mathrm{X}_{3}=$ the total of family member (people)

$\mathrm{X}_{4}=$ land area

$\mathrm{X}_{5}=$ urea fertilizer price (IDR/kg)

$\mathrm{X}_{6}=$ phonska fertilizer price (IDR/kg)

$\mathrm{X}_{7}=$ seed price (IDR/kg)

$\mathrm{X}_{8}=$ cooking oil price (IDR/lt)

$\mathrm{X}_{9}=$ white sugar price (IDR/kg)

$\mathrm{X}_{10}=$ egg price $(\mathrm{Rp} / \mathrm{kg})$

$\mathrm{X}_{11}=$ total household income $(\mathrm{Rp} / \mathrm{year})$

$\mu=$ error term

Table 1. The Group and Main Indicators of LVI

\begin{tabular}{ll}
\hline Group Indicator & Main Indicator \\
\hline Exposure & Natural Disaster and Climate Variability \\
Sensitivity & Farming, Foods, Water \\
Adaptive capacity & Consumption, Education, Income \\
\hline Source: Hahn et al. (2009) modified by Murniati et al. (2017)
\end{tabular}

\begin{tabular}{|c|c|c|c|}
\hline \multirow{2}{*}{$\begin{array}{l}\text { Adequate food } \\
\text { supply }\end{array}$} & \multicolumn{3}{|c|}{$\begin{array}{c}\text { The consumption frequency of } \\
\text { household member }\end{array}$} \\
\hline & $\geq 3$ times & 2 times & 1 time \\
\hline$\geq 240$ days & Stabile & Less stable & Unstable \\
\hline 1-239 days & Less stable & Unstable & Unstable \\
\hline There is no inventory & Unstable & Unstable & Unstable \\
\hline
\end{tabular}

Table 2. The household food supply stability category 
Table 3. Household food accessibility category

\begin{tabular}{lll}
\hline Field ownership & \multicolumn{2}{c}{ The way of household gain feed } \\
\hline Exist & Direct access & Indirect access \\
No exist & Indirect access & \\
\hline
\end{tabular}

Table 4. The household food supply continuity

\begin{tabular}{llll}
\hline \multirow{2}{*}{ Food } & \multicolumn{3}{l}{ Household food supply stability } \\
\cline { 2 - 4 } accessibility & Stable & Less stable & Unstable \\
\hline Direct access & Continuous & Incontinuous & Incontinuous \\
Indirect access & Less & Incontinuous & Incontinuous \\
& continuous & & \\
\hline
\end{tabular}

Table 5. The household food security index

\begin{tabular}{|c|c|c|c|}
\hline \multirow[b]{2}{*}{$\begin{array}{l}\text { Continuous } \\
\text { food supply }\end{array}$} & \multicolumn{3}{|c|}{$\begin{array}{c}\text { Food quality/security: Plant and/or animal protein } \\
\text { consumption }\end{array}$} \\
\hline & $\begin{array}{l}\text { Plant and animal } \\
\text { protein/only } \\
\text { animal protein }\end{array}$ & $\begin{array}{l}\text { Only plant } \\
\text { protein }\end{array}$ & $\begin{array}{l}\text { No animal and } \\
\text { plant protein } \\
\text { consumption }\end{array}$ \\
\hline Continuous & Secure & Less secure & Insecure \\
\hline Less continuous & Less Secure & Insecure & Insecure \\
\hline Incontinuous & Insecure & Insecure & Insecure \\
\hline
\end{tabular}

Source: Aswatini et al (2004)

\section{RESULTS AND DISCUSSION}

\section{The upland rice farmer household livelihood vulnerability against the climate change}

The household livelihood vulnerability was measured using the indicators developed by Hahn et al. (2009), namely: Exposure, sensitivity, and adaptive capacity, whereas the primary indicators were based on the indicators modified by Murniati et al. (2017). The main indicators for the exposure included the natural disasters and climate variability; The main indicators for sensitivity contained food, farming, and water, while the main indicators of the adaptive capacity are consumption, education, and income. The result of the upland rice farmer livelihood vulnerability index is presented in Table 6 .

According to Table 6 and Figure 1, the LVI index is 0.3867, and LVI-IPCC is 0.071, which belongs to the medium category. The indicators for the domestic farmer household level on natural disasters and climate change are relatively high at 0.713 . This condition was different from Kiflii, Mulyo and Sugiyarto (2015), who stated that the index of farmer household exposure was 0.2508 , belonged to the medium category, while Murniati et al. (2017) stated that the organic and non-organic rice farmers on the rainfed field in Pematang Sawa Tanggamus district was 0.44, which was relatively closed to the high category. The sensitivity score of 0.221 in the medium category is shown to be the highest index among water and food. This was due to the small land area use for farming with an average of 0.35 ha, which is then classified as small farmers (gurem). In addition, some of the rice farmer households only work on two types of crops (rice and corn), and 60\% of households rely on agriculture as a major income. A small area of upland rice cultivation land and dependence on rice farming as the main job, besides the climate change impact, cause the farmer's livelihood to be sensitive against climate change.

The adaptation capacity score is 0.393 , which belongs to the medium category as most farmers $(91 \%)$ belong to the low educational background (8 years). The low education of farmers causes less farming management capability and climate change impact that affects the farming activity (Hidayati and Suranto 2015; Li et al. 2017; Fagariba et al. 2018; Yanfika et al. 2019), resulting in the upland rice productivity only reaches 1.9 tons per ha. Meanwhile, the upland rice productivity by applying the integrated crop management (PTT) can reach 5.9 tons/ha (Toha 2007). Therefore, in the future, extension support is needed in good management of farm rice. In addition, the need to prepare adaptation strategies and farmers' livelihood strategies to the effects of climate change so that farmers are able to adapt to the adverse effects of climate change.

\section{The upland rice farmer household food security index}

The household food security is the description of the general food supply situation at the household level, which will describe the food supply situation in a particular region. In this research, the household food security level measured by four components of household food security, namely the adequacy of food availability, the stability of food supply, food accessibility, and food quality (Aswatini et al. 2004). The food security level can also be seen from the process and impact indicators. Food supply and accessibility is the process indicator of food security, describing the food situation of the farmer's household. In contrast, food consumption is a direct impact indicator of food security described by the quantity and quality of farmer household food consumption. The direct impact indicators are food consumption and frequency, while the indirect impact indicators are the storage and nutritional status (Jones et al. 2013; Kuchenbecker et al. 2017; Reber et al. 2019). The degree of rice farmer household food security is presented in Table 7 .

Based on Table 7, most upland rice farmers (77.27\%) belonged secure food category, and others (22.73\%) categorized as less food secure categories. The "secure" category in the food security index is obtained if the upland rice farmers fulfill three criteria includes food availability $\geq 240$ days, food stability is in the stabile category, and food sustainability is in the continuous category. If the upland rice farmers only fulfill one from the three criteria, then the index of food security is included in the category of "less secure category." If it only fulfills one or less of the three criteria, it falls into the category of "insecure" in the food security index.

Many households become secure food category due to the continuous food availability and good quality of food consumption. This condition was reflected from the number of ricer field farmer households that have adequate food available for more than 240 days, and $100 \%$ farmer households have direct food access, therefore able to consume food with three times a day frequency. Besides, 
the secure food category also determines the good food consumption containing animal and plant protein or animal protein only.

Furthermore, Table 7 explains that there are still upland rice farmer households who are in the less food secure category due to less continuous food supply and poor quality of food consumption reflected from the food supply with the food consumption was less than 240 days and two times food consumption frequency, containing only plant proteins. Based on the result, it appears that there is a correlation between the farmer's household food security with food availability, accessibility, and consumption. This was in line with Saputri, Lestari, and Susilo (2016), who concluded that there was a meaningful correlation between the household food security in Kampar District, Riau Province with the food consumption pattern and external variables (the number of household members, food accessibility, family spending, energy consumption, and protein consumption).

\section{The correlation of livelihood vulnerability and food security in upland rice farmer household}

The correlation analysis result of upland rice farmer livelihood vulnerability against climate change and food security is presented in Table 8.

Based on the regression analysis result in Table 8, some variables that have a statistically significant effect on the food security of rice farmer households in Sidomulyo Subdistrict are Stadaptation, Pphonska, and Price. The adaptation strategies of upland rice farmers against the climate change impact can be applied through (i) The unclockwise contour soil treatment, this strategy is useful for reducing surface run-off and removing layers of soil that are rich in nutrients (ii) The minimum soil tillage, this strategy is useful for increasing tenure, preventing soil saturation and damage to soil structure (iii) Increased weeds removal intensity, this strategy is useful so that plants obtain nutrients optimally, (iv) Early planting during the rainy season, this strategy aims to speed up the harvest period and obtain an adequate water supply (v) The application of multiple cropping (tumpang sari) or overlapping (tumpang giling) system, (vi) Planting time adjustment, (vii) The use of plant spacing recommendations, and (viii) Crop rotation in a more disciplined manner. These strategies show tangible and positive influences on the farmer's household food security.
The positive influence is the probability of the upland rice farmer's household odd ratio to be in the food-secure category.

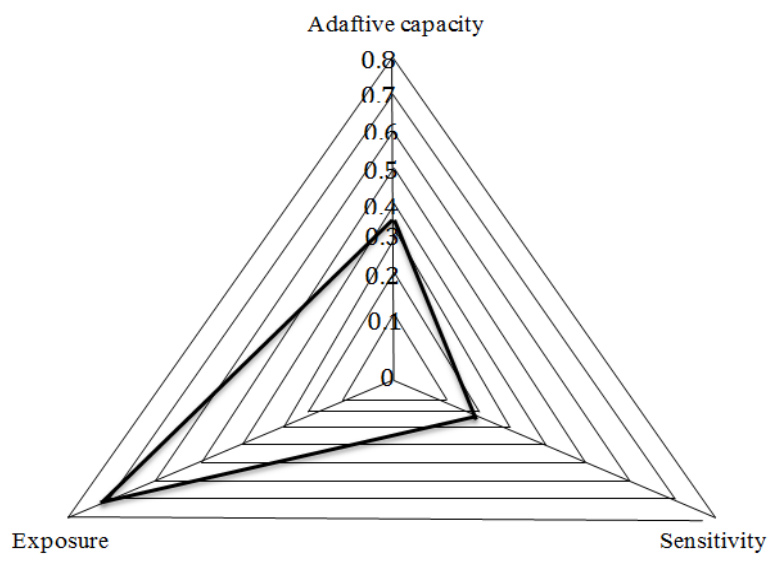

Figure 1. Triangle diagram of the upland rice farmer household livelihood vulnerability against the climate change impact

Table 7. The upland rice farmer household food security

\begin{tabular}{|c|c|c|c|}
\hline No & Description & $\begin{array}{c}\text { Total } \\
\text { household }\end{array}$ & $\begin{array}{c}\text { Percentage } \\
(\%)\end{array}$ \\
\hline \multirow[t]{4}{*}{1} & Food supply: & & \\
\hline & Supply $\geq 240$ days & 51 & 77,27 \\
\hline & Supply $1-239$ days & 15 & 22,73 \\
\hline & No supply & - & - \\
\hline \multirow[t]{4}{*}{2} & Food stability: & & \\
\hline & Stabile & 51 & 77,27 \\
\hline & Less stabile & 15 & 22,73 \\
\hline & Unstable & - & - \\
\hline \multirow[t]{3}{*}{3} & Accessibility: & & \\
\hline & Direct & 66 & 100,00 \\
\hline & Indirect & - & - \\
\hline \multirow[t]{4}{*}{4} & Continuity: & & \\
\hline & Continuous & 51 & 77,27 \\
\hline & Less continuous & 15 & 22,73 \\
\hline & Incontinuous & - & - \\
\hline \multirow[t]{4}{*}{5} & Food security index: & & \\
\hline & Secure & 51 & 77,27 \\
\hline & Less secure & 15 & 22,73 \\
\hline & Insecure & - & - \\
\hline
\end{tabular}

Table 6. The upland rice farmer household livelihood index against the climate change in Lampung Province

\begin{tabular}{llcccc}
\hline $\begin{array}{c}\text { Contribution } \\
\text { factor }\end{array}$ & \multicolumn{1}{c}{ Main component } & $\begin{array}{c}\text { Main } \\
\text { component } \\
\text { value }\end{array}$ & $\begin{array}{c}\text { Total sub- } \\
\text { component }\end{array}$ & $\begin{array}{c}\text { Contribution } \\
\text { factor value }\end{array}$ & $\begin{array}{c}\text { LVI } \\
\text { of upland } \\
\text { rice }\end{array}$ \\
\hline Adoption & Consumtion & 0.270 & 3 & & 0.38 \\
capacity & Education & 0.910 & 1 & 0.393 & 67 \\
& Income & 0.320 & 2 & & \\
Sensitivity & Food & 0.036 & 5 & & \\
& Agriculture & 0.354 & 4 & 0.221 & \\
& Water & 0.299 & 5 & & \\
Exposure & Natural disaster and climate variability & 0.713 & 7 & 0.713 \\
\hline
\end{tabular}


Table 8. The analysis result of logic ordinal of factors affecting the upland rice farmer household food security degree

\begin{tabular}{|c|c|c|c|c|c|}
\hline Variable & Coefficient & Std. Error & Z-Statistic & Probability & OR \\
\hline$\overline{\text { Cutt off/Limit } 1}$ & -68.461 & & & & \\
\hline Cutt off/Limit 2 & -61.38696 & & & & \\
\hline S Adaptation & 1.207671 & .4246113 & 2.84 & $0.004 * * *$ & 3.345683 \\
\hline P Climate & -.008283 & 1.894435 & -0.00 & 0.997 & .9917512 \\
\hline Pdk & .183104 & .2717517 & 0.67 & 0.500 & 1.200939 \\
\hline Jak & -.2928114 & .8276775 & -0.35 & 0.724 & .7461628 \\
\hline L Land & 6.33542 & 4.132465 & 1.53 & 0.125 & 564.2065 \\
\hline P Urea & -.0028962 & .0039201 & -0.74 & 0.460 & .997108 \\
\hline P phonska & -.0117956 & .0045526 & -2.59 & $0.010 * *$ & .98822737 \\
\hline $\mathrm{P}$ seed & -.0007575 & .000815 & -0.93 & 0.353 & .9992428 \\
\hline Price & -.0020187 & .0009541 & -2.12 & $0.034 *$ & .9979834 \\
\hline Pcooking oil & .0001999 & .0007925 & 0.25 & 0.801 & 1.0002 \\
\hline Psugar & -.0002503 & .0007318 & -0.34 & 0.732 & .9997498 \\
\hline Pegg & -.0004061 & .000251 & -1.62 & 0.106 & .999594 \\
\hline
\end{tabular}

Note $* * *$ significance on $99 \%$ degree of confidence $(\alpha=0.01)$ **significance on $95 \%$ degree of confidence $(\alpha=0.05)$. *significance on $90 \%$ degree of confidence $(\alpha=0.10)$

The input price factor that affects the food security status of upland rice farmer households is the phonska fertilizer price. Negative coefficient value marked that increased fertilizer price will significantly decrease the rice farmer's household probability to be food secure. Another factor affecting household food security is the rice price. The rice price statistically correlates negatively against the household probability for the food security status. This means that increased rice price will lower the probability of rice farmer households to be secure food status. It can also be explained in Table 8 that the head of the family educational background and income as the adaptation capacity proxy had no significant effect against the food security status of the upland rice farmer households.

In conclusion, based on the contribution value of LVIIPCC, the livelihood vulnerability of upland rice farmer households in Sidomulyo Sub-district, South Lampung District, against the climate change impact belongs to the medium category. The indicators for the domestic farmer household level on natural disasters and climate change (exposure factor) are relatively high at 0.713 . The sensitivity score of 0.221 in the medium category. The adaptation capacity score is 0.393 , which belongs to the medium category. In the food security index aspect, most upland rice farmers $(77.27 \%)$ belonged to a secure food category, and around $22.73 \%$ categorized as less secure categories. The adaptation strategy of climate change impact, phonska fertilizer price, and rice price statistically affect the food security of rice farmer households. Therefore, climate change adaptation strategies are necessary for sustained food security.

\section{ACKNOWLEDGEMENTS}

The authors would like to thank to the farmers in Sidomulyo Sub-district, South Lampung District and the enumerators who helped to collect research data, and to the University of Lampung for supporting this research.

\section{REFERENCES}

Ali S, Liu Y, Ishaq M, Shah T, Abdullah IA, Din IU. 2017. Climate Change and Its Impact on the Yield of Major Food Crops: Evidence from Pakistan. Foods 6 (6): 39. DOI: 10.3390/foods6060039.

Anríquez G, Toledo G. 2019. De-climatizing food security: Lessons from climate change micro-simulations in Peru. PLoS ONE 14(9): e0222483. DOI: 10.1371/journal.pone.0222483.

Asmare B, Meheret F. 2018. Smallholder farmers livestock production on the face of climate change in Bahir Dar, Zuria District, Northwestern Ethiopia. Biodiversitas 19 (6): 2329-2334

Aswatini H, Romdiati B, Setiawan A, Latifa, Fitrianita, Noveria M. 2004. Ketahanan Pangan, Kemiskinan dan Sosial Demografi Rumah Tangga. Pusat Penelitian Kependudukan, LIPI, Jakarta. [Indonesian]

Bande LOS, Hadisutrisno B, Somowiyarjo S, Sunarminto BH. 2015. The Role of Weather Elements Toward Increased Foot Rot Disease on Black Pepper in the Production Center of Southeast Sulawesi. Jurnal Manusia dan Lingkungan, 22 (2): 187-193.

Eitzinger A, Binder CR, Meyer MA. 2018. Risk perception and decisionmaking: do farmers consider risks from climate change? Climatic Change 151, 507-524. DOI: 10.1007/s10584-018-2320-1

Fagariba CJ, Song S, Baoro SKGS. 2018. Climate Change Adaptation Strategies and Constraints in Northern Ghana: Evidence of Farmers in Sissala West District. Sustainability 10 (5): 1484 . DOI: 10.3390/su1005148.

Fahad S. Bajwa AA. Nazir U. Anjum SA. Farooq A. Zohaib A. Sadia S. Nasim W. Adkins S. Saud S. Ihsan M. Z. Alharby H. Wu C. Wang D. Huang J. 2017. Crop Production under Drought and Heat Stress: Plant Responses and Management Options. Front Plant Sci 8: 1147. DOI: 10.3389/fpls.2017.01147.

Ferrante A, Mariani L. 2018. Agronomic Management for Enhancing Plant Tolerance to Abiotic Stresses: High and Low Values of Temperature, Light Intensity, and Relative Humidity. Horticulturae 4 (21): 1-19.

Firdaus RBR, Gunaratne, MS, Rahma SR, Kamsi NS. 2019. Does climate change only affect food availability? What else matters? Cogent Food \& Agriculture 5: 1. DOI: 10.1080/23311932.2019.1707607.

Francl LJ. 2001. The Disease Triangle: A plant pathological paradigm revisited. The Plant Health Instructor. DOI: 10.1094/PHI-T-20010517-01.

Fuadi NA, Purwanto MYJ, Tarigan SD. 2016. Study on Water Requirement and Water Productivity of Paddy Field with Sri and Conventional Water Supply System By Using Pipe Irrigation. Jurnal Irigasi 11 (1): 23-32.

Gateau-Rey L, Tanner EVJ, Rapidel B, Marelli JP, Royaert S. 2018. Climate change could threaten cocoa production: Effects of 2015-16 El Niño-related drought on cocoa agroforests in Bahia, Brazil. PLoS ONE 13(7): e0200454. DOI: 10.1371/journal.pone.0200454. 
Hahn MB, Riederer AM, Foster SO. 2009. The Livelihood Vulnerability Index: A pragmatic approach to assessing risks from climate variability and change- A case study in Mozambique. Global Environ Change 19 (1): 74-88.

Harvey CA, Rakotobe ZL, Rao NS, Dave R, Razafimahatratra H, Rabarijohn RH, Rajaofara H, MacKinnon JL. 2014. Extreme vulnerability of smallholder farmers to agricultural risks and climate change in Madagascar. Phil. Trans. R. Soc. B 369: 20130089. DOI: 10.1098/rstb.2013.0089

Hidayati IN, Suryanto. 2015. Pengaruh Perubahan Iklim Terhadap Produksi Pertanian dan Strategi Adaptasi pada Lahan Rawan Kekeringan. Jurnal Ekonomi dan Studi Pembangunan 16 (1): 42-52.

IPCC. 2007. Climate Change 2007. Impacts, Adaptation and Vulnerability Contribution of Working Group II to the Fourth Assessment Report of the Intergovernmental Panel on Climate Change (IPCC). M.L. Parry, O>F Canziani. J.P Palutikof, P.J van der Linden and C.E. Hanson (Eds) Cambridge University Press. Cambridge.

Islam MDS, Wong AT. 2017. Climate Change and Food In Security: A Critical Nexus. Environments 4 (38): 1-15.

Jessica RR, James M, Russell MV, Sylvia D, Brent L, Satria, B. 2018. La Niña-driven flooding in the Indo-Pacific warm pool during the past millennium. Quaternary Science Reviews 225: 106020.

Jones AD, Ngure FM, Pelto G, Young SL. 2013. What are we assessing when we measure food security? A compendium and review of current metrics. Adv Nutr 4 (5): 481-505. DOI 10.3945/an.113.004119

Kementerian Pertanian. 2016. Outlook Padi 2016. Pusat Data Kementerian Pertanian, Jakarta. [Indonesian]

Komariah, Senge M, Sumani, Dewi WS, Yoshiyama K, Rachmadiyanto AN. 2015. The Impacts of Decreasing Paddy Field Area on Local Climate in Central Java, Indonesia. Air Soil Water Res 8: 77-85.

Korres NE, Norsworthy JK, Tehranchian P, Gitsopoulos TK, Loka DA, Oosterhius DM, Gealy DR, Moss SR, Burgos NR, Miller MR, Palhano M. 2016. Cultivars to face climate change effects on crops and weeds: a review. Agron Sustain Dev 36 (12). DOI 10.1007/s13593-016-0350-5

Kuchenbecker J, Reinbott A, Mtimuni B, Krawinkel MB, Jordan I. 2017. Nutrition education improves dietary diversity of children 6-23 months at community-level: Results from a cluster randomized controlled trial in Malawi. PLoS ONE 12(4): e0175216. DOI: 10.1371/journal.pone.0175216

Li S, Juhasz-Horvath L, Harrison PA, Pinter L, Rounsevell MDA. 2017. Relating farmer's perceptions of climate change risk to adaptation behaviour in Hungary. J Environ Manage 185: 21-30

Listiana I, Efendi I, Mutolib A, Rahmat A. 2019. The behavior of Extension Agents in Utilizing Information and Technology to Improve the Performance of Extension Agents in Lampung Province. J Phys: Conf Ser 1155 012004 DOI: 10.1088/17426596/1155/1/012004

Mashizha TM. 2019. Adapting to climate change: Reflections of peasant farmers in Mashonaland West Province of Zimbabwe. Jamba 11 (1) 571. DOI: 10.4102/jamba.v11i1.571

Ministry of Agriculture of Indonesia. 2018. Luas Panen Padi Sawah di Indonesia Menurut Provinsi, 2014 - 2018. [Indonesian] https://www.pertanian.go.id/Data5tahun/TPATAP-2017(pdf)/11LPPadiSawah.pdf

Misra AK. 2014. Climate change and challenges of water and food security. Int J Sustainable Built Environ 3 (1): 153-165

Murniati K, Mulyo JH, Irham, Hartono S. 2017. The Livelihood Vulnerability to Climate Change of Two Different Farmer Communities in Tanggamus Region, Lampung Province, Indonesia. Asian J Agric nd Deve 14 (2): 1-16.

Murniati K, Widjaya S, Adawiyah R, Listiana I. 2019. Climate Change Adaptations Strategy for Sustainability and Food Security of Cassava Farming Households in Lampung Indonesia. J Agric Extens 23 (2) :138-146.
Mutolib A, Yonariza, Mahdi, Ismono H. 2017. Gender Inequality and the Oppression of Women within Minangkabau Matrilineal Society: A Case Study of the Management of Ulayat Forest Land in Nagari Bonjol, Dharmasraya District, West Sumatra Province, Indonesia. Asian Women 32 (3): 23-49.

Prajanti SDW, Susilowati I. 2016. The Prospect of Integrated Farming System of Crops-fish husbandry as the Survival Strategy to Secure the Farmers' Economy: Case Study in Magelang - Indonesia. International Journal of Economics and Financial 6 (S6): 84-87.

Rahmat A, Zaki MK, Effendi I, Mutolib A, Yanfika H, Listiana I. 2019. Effect of global climate change on air temperature and precipitation in six cities in Gifu Prefecture, Japan. IOP Conf. J Phys: Conf Ser 1155 012070. DOI: 10.1088/1742-6596/1155/1/012070

Rahmat A. Hamid MA, Zaki MK, Mutolib A. 2018. Normalized Difference Vegetation Index in the Integration of Conservation Education. Indonesian J Sci Technol 3 (1): 47-52.

Rahmat A, Mutolib A, Iresha FM, Zaki MK, Prasetyo B. 2020. Life cycle and potential of black soldier fly (Hermatia illucens) for waste composting. International Journal of Applied Science for Environment 1(1): In press

Raza A, Razzaq A, Mehmood SS, Zou X, Zhang X, Lv Y, Xu, J. 2019. Impact of Climate Change on Crops Adaptation and Strategies to Tackle Its Outcome: A Review. Plants 8 (2): 34. DOI: 10.3390/plants8020034

Reber E, Gomes F, Vasiloglou MF, Schuetz P, Stanga Z. 2019. Nutritional Risk Screening and Assessment. J Clin Med 8 (7): 1065. DOI: $10.3390 / \mathrm{jcm} 8071065$

Santoso AB. 2016. The Impact of Climate Change on Food Crops Production in the Province of Maluku. Penelitian Pertanian Tanaman Pangan 35(1): 29-38.

Saputri L, Lestari LA, Susilo J. 2016. Pola Konsumsi Pangan dan Tingkat Ketahanan pangan Rumah tangga di Kabupaten Kampar Provinsi Riau. Jurnal Gizi Klinik Indonesia 12 (3): 123-130. [Indonesian]

Sintayehu DW. 2018. Impact of climate change on biodiversity and associated key ecosystem services in Africa: a systematic review. Ecosyst Health Sustainability 4 (9): 225-239. DOI: 10.1080/20964129.2018.1530054

Srivastava AK, Rai MK. 2012. Review: Sugarcane production: Impact of climate change and its mitigation. Biodiversitas 13 (4): 214-227.

Thornton P, Dinesh D, Cramer L, Loboguerrero AM, Campbell B. 2018. Agriculture in a changing climate: Keeping our cool in the face of the hothouse. Outlook of Agriculture 47 (4): 283-290.

Toha HM. 2007. Peningkatan produktivitas padi gogo melalui penerapan pengelolaan tanaman terpadu dengan introduksi varietas unggul. Balai Besar Penelitian Tanaman Padi. Penelitian Pertanian Tanaman Pangan 26 (3). [Indonesian]

Utami AW, Jamhari, Hardyastuti S. 2011. El Nino, La Nina, Dan Penawaran Pangan di Jawa, Indonesia. Jurnal Ekonomi Pembangunan 12 (2): 257-271. [Indonesian]

Utami TI, Handayani T, Kuswantoro. 2019. Exposure of dryland Farming to the ENSO Phenomenon in Kebumen District. IOP Conf Series: Earth and Environmental Science 303 (2019) 012024. DOI: 0.1088/1755-1315/303/1/012024

Widada AW, Hardyastuti S, Mulyo JH, Irham. 2014. Analisis Kerentanan Penghidupan Rumah Tangga Tani Akibat Perubahan Iklim di Kabupaten Gunung Kidul. Jurnal Agro Ekonomi 24 (1): 10-24. [Indonesian]

Yanfika H, Listiana I, Mutolib A, Rahmat A. 2019. Linkages between Extension Institutions and Stakeholders in the Development of Sustainable Fisheries in Lampung Province. IOP Conf. Series: Journal of Physics: Conf. Series 1155 (2019) 012014. DOI: 10.1088/1742-6596/1155/1/012014

Zwane EM. 2019. Impact of climate change on primary agriculture, water sources and food security in Western Cape, South Africa. Jamba 11 (1): 562. DOI: $10.4102 /$ jamba.v11i1 